\section{Priming Leek Seed for Improved Germination and Emergence at High Temperature}

\author{
Carlos A. Parera and Daniel J. Cantliffe \\ Vegetable Crops Department, University of Florida, Gainesville, \\ FL 32611
}

Additional index words. Allium porrum, seed treatment, osmotic solutions, vegetable crops

Abstract. 'Verina' leek (AIlium porrum L.) seed germination is normally reduced at temperatures $>25 \mathrm{C}$. Leek seeds were primed in aerated solutions (- $1.5 \mathrm{MPa}, 10$ days at 15C) of d-mannitol (mannitol), polyethylene glycol-8000 (PEG $)_{\mathrm{a}}$, $\mathrm{KNO}_{3}$, and a nonaerated solution of PEG-8000 (PEG ${ }_{\text {na }}$ ). At high temperatures mannitol, PEG $_{a}$, and PEG $_{\mathrm{n}}$ significantly enhanced germination percentage relative to $\mathrm{KNO}_{3}$, or the control. At constant $30 \mathrm{C}$, the mannitol, $\mathbf{P E G}_{\mathrm{a}}$, and $\mathbf{P E G}_{\text {na }}$ treatments increased final germination almost 10 times and the coefficient of velocity $(\mathrm{COV})$ was improved compared to $\mathrm{KNO}_{3}$, and the control. 10 growth chambers with alternating day/night temperatures (38 to $28 \mathrm{C}$ or 32 to $22 \mathrm{C}, 10$ to 14 hours, respectively), primed seeds had significantly higher emergence and a larger $\mathrm{COV}$ than the control. In a greenhouse study under good conditions for germination, total emergence of primed and nonprimed seeds was similar; however, mannitol, PEG, and PEG led to a significantly higher COV than the control or $\mathrm{KNO}_{3}$, treatments. These controlled-environment results demonstrate that priming leek seeds via mannitol, PEG $_{\mathbf{a}}$, and PEG $_{\text {nа }}$ may promote early emergence at high temperature and improve stand uniformity for container transplant production.
The period between planting seeds and the emergence of the seedlings is critical for stand establishment and the eventual yield of most crops. In Florida, leek is generally established by transplanting in the fall. Because plants for this production must be sown in July and August, containerized leek transplant production is susceptible to heat stress, resulting in poor and nonuniform seedlings. Seed priming has increased the uniformity and early emergence of many crops, especially under conditions of environmental stress (Bradford, 1986). Plant establishment becomes extremely difficult at high temperature (Cantliffe, 1989). Seed priming with $\mathrm{K}_{3} \mathrm{PO}_{4}$ has successfully increased the germination percentage and rate for lettuce (Lactuca sativa L.) seeds sown at high temperature (Guedes and Cantliffe, 1980). Under heat stress, the time required for the emergence of tomato (Lycopersicum esculentum Mill.) seedlings was reduced and higher uniformity was achieved by priming in $\mathrm{K}_{3} \mathrm{PO}_{4}+\mathrm{KNO}_{3}$ solution (Ode11 and Cantliffe, 1987). Pansy (Viola tricolor L.) seeds primed in aerated solutions of PEG 8000 had significantly higher germination at $35 \mathrm{C}$ than

Received for publication 18 Sept. 1991. Accepted for publication 19 May 1992. Univ. of Florida Agr. Expt. Sta. J. Ser. no. R-01760. The cost of publishing this paper was defrayed in part by the payment of page charges. Under postal regulations, this paper therefore must be hereby marked advertisement solely to indicate this fact. nonprimed seeds (Carpenter and Boucher, 1991).

Leek seed is characterized by low emergence percentage, which leads to poor stands (Brocklehurst et al., 1984). Seed primed in nonaerated PEG solutions has been reported as an effective presowing treatment in leek the uniformity of germination (Bray et al., 1989; Brocklehurst et al., 1984). However, the experiments reported were conducted at low temperature (15C). Our objective was to compare priming treatments to improve germination and emergence of leek under heat stress.

Seeds of 'Verina' leek (Northrup King, Gilroy, Calif.) were used in all experiments. Two hundred seeds $(0.44 \mathrm{~g})$ were soaked in $35 \mathrm{ml}$ of osmotic solution (- $1.5 \mathrm{MPa})$ of D-mannitol, polyethylene glycol-8000 ( $\left.\mathrm{PEG}_{\mathrm{a}}\right)$, or $\mathrm{KNO}_{3}$ in $150-\mathrm{mm}$ test tubes and aerated with an aquarium pump. The water potential of the solutions was measured in a Wescor vapor pressure osmometer (Wescor, Logan, Utah) at 25C. The priming treatments were for 10 days at $15 \mathrm{C}$ in dark. The nonaerated priming treatment $\left(\mathrm{PEG}_{\mathrm{na}}\right)$ consisted of placing 200 seeds on filter paper (Whatman \#3) moistened with $5 \mathrm{ml}$ of PEG-8000 at -1.5 $\mathrm{MPa}$ in a $9-\mathrm{mm}$ petri dish. The container was sealed with parafilm (American National Can, Greenwich, Conn.) to prevent water evaporation. It has been reported that the filter paper lowers the original water potential when the ratio volume of solution, air dry weight of the filter paper, is $<12$ (Hardegree and Emmerich, 1990). In our experiment the ratio was 5 ; thus, we expected a more negative water potential $(-0.02 \mathrm{MPa})$ than the original solution. The soak time and temperature for nonaerated priming were the same as described for the aerated treatments. After priming, the seeds were rinsed with tap water (1 min) and dried back to the original fresh weight $(6.2 \%)$ at $15 \mathrm{C}$ and $30 \%$ relative humidity (RH). The seeds were stored before for reducing the mean time and increasing

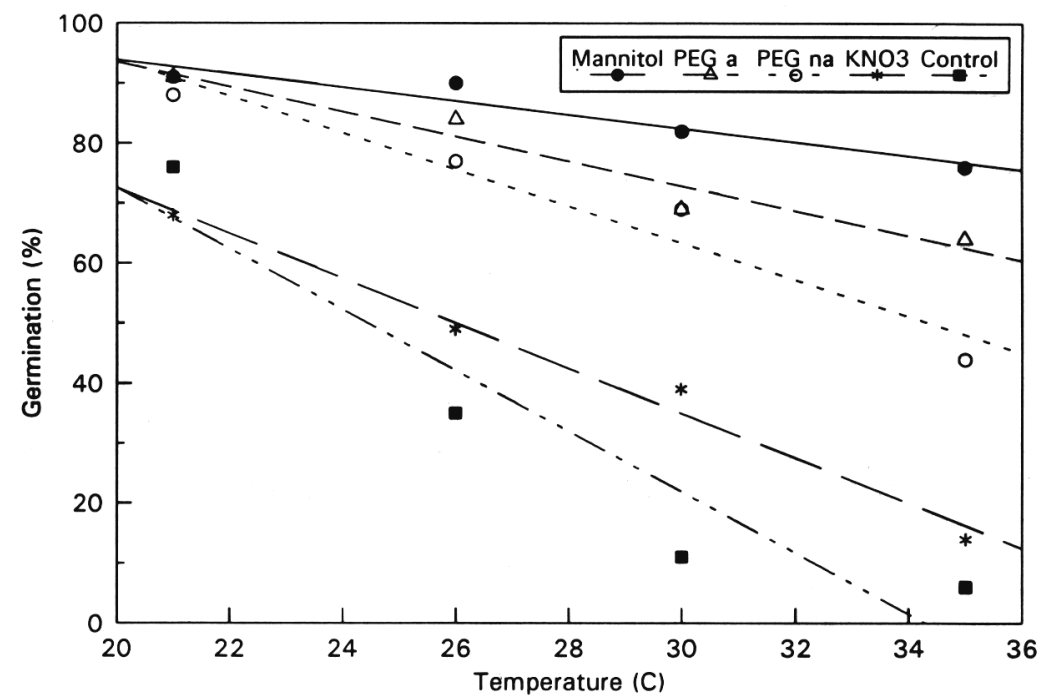

Fig. 1. Relationship between temperature $\left({ }^{\circ} \mathrm{C}\right)$ and germination $(\%)$ of 'Verina' leek in response to priming treatments. The regression equations for the lines were: mannitol: $\mathrm{y}=116.7-1.14 \mathrm{x}\left(R^{2}\right.$ $=0.55) ; \mathrm{PEG}_{\mathrm{a}}: \mathrm{y}=136.9-2.13 \mathrm{x}\left(R^{2}=0.72\right) ; \mathrm{PEG}_{\mathrm{na}}: \mathrm{y}=155.1-3.06 \mathrm{x}\left(R^{2}=0.41\right) ; \mathrm{KNO}_{3}$ : $\mathrm{y}=147.4-3.7 \mathrm{x}\left(R^{2}=0.62\right)$; control: $\mathrm{y}=174.1-5.08 \mathrm{x} \quad\left(R^{2}=0.78\right)$. Treatments: mannitol: aerated solution; PEG $_{\mathrm{a}}$ : aerated solution PEG-8000; PEG-8000; PEG-8600 on filter paper; $\mathrm{KNO}_{3}$ : aerated solutions $\mathrm{KNO}_{3}$. All: - $1.5 \mathrm{MPa}$, treated 10 days at $15 \mathrm{C}$. Control: nonprimed seeds. 
Table 1. Final germination percentage (7 days) of 'Verina' leek at various temperatures on a thermogradient table as influenced by priming treatment.

\begin{tabular}{lllcrr}
\hline \hline & \multicolumn{5}{c}{ Temp $\left({ }^{\circ} \mathrm{C}\right)$} \\
\cline { 2 - 6 } Treatment $^{2}$ & 21 & 26 & 30 & 35 & LSD (0.05) \\
\hline & & & Germination (\%) & \\
Mannitol & 91 & 90 & 82 & 76 & 9 \\
PEG $_{\text {a }}$ & 91 & 84 & 69 & 64 & 10 \\
PEG $_{\text {na }}$ & 88 & 77 & 69 & 44 & 32 \\
KNO $_{3}$ & 68 & 49 & 39 & 14 & 20 \\
Control & 76 & 35 & 11 & 6 & 20 \\
LSD (0.05) & NS & 18 & 26 & 22 & \\
\hline
\end{tabular}

${ }^{2}$ Mannitol: aerated solution; $\mathrm{PEG}_{\mathrm{a}}$ : aerated solution of PEG-8000, $\mathrm{PEG}_{\mathrm{n}}$ : PEG-8000 on filter paper; $\mathrm{KNO}_{3}$ : aerated solutions $\mathrm{KNO}_{3}$. All: $-1.5 \mathrm{MPa}$, treated 10 days at $15 \mathrm{C}$. Control: nonprimed seeds.

Table 2. Final emergence percentage and coefficient of velocity (COV) of primed and nonprimed seeds of 'Verina' leek at constant and alternating temperatures.

\begin{tabular}{|c|c|c|c|c|c|c|c|c|}
\hline \multirow[b]{3}{*}{ Treatment $^{2}$} & \multicolumn{8}{|c|}{ Day/night temp $\left({ }^{\circ} \mathrm{C}\right)$} \\
\hline & \multicolumn{2}{|l|}{$30^{y}$} & \multicolumn{2}{|c|}{38 to $28^{x}$} & \multicolumn{2}{|c|}{32 to $22^{x}$} & \multicolumn{2}{|c|}{34 to $24^{w}$} \\
\hline & $\begin{array}{c}\text { Germination } \\
(\%)\end{array}$ & $\mathrm{COV}$ & $\begin{array}{c}\text { Emergence } \\
(\%)\end{array}$ & $\mathrm{COV}$ & $\begin{array}{c}\text { Emergence } \\
(\%)\end{array}$ & $\mathrm{COV}$ & $\begin{array}{c}\text { Emergence } \\
(\%)\end{array}$ & $\mathrm{COV}$ \\
\hline Mannitol & 55 & 25.3 & 43 & 13.0 & 55 & 21.7 & 71 & 21.3 \\
\hline PEG & 48 & 23.9 & 35 & 12.2 & 49 & 19.7 & 71 & 21.3 \\
\hline $\mathrm{PEG}$ & 49 & 26.8 & 38 & 11.5 & 41 & 20.3 & 67 & 20.9 \\
\hline $\mathrm{KNO}_{3}$ & 6 & 20.5 & 23 & 10.8 & 40 & 18.8 & 51 & 18.3 \\
\hline Control & 6 & 18.9 & 15 & 9.3 & 16 & 10.6 & 63 & 15.8 \\
\hline LSD $(0.05)$ & 13 & 4.2 & 9 & 1.2 & 19 & 3.6 & NS & 2.3 \\
\hline
\end{tabular}

${ }^{2}$ Mannitol: aerated solution; $\mathrm{PEG}_{\mathrm{a}}$ : aerated solution PEG-8000; $\mathrm{PEG}_{\mathrm{m}}$ : $\mathrm{PEG}-8000$ on filter paper; $\mathrm{KNO}_{3}$ : aerated solutions $\mathrm{KNO}_{3}$. All: $-1.5 \mathrm{MPa}$, treated 10 days at $15 \mathrm{C}$. Control: nonprimed seeds. Incubator.

${ }^{x}$ Growth chamber.

"Greenhouse.

and after treatment at $10 \mathrm{C}$ and $45 \%$ RI-I.

Germination tests were conducted on a thermogradient table $(21$ to $35 \mathrm{C})$ in darkness. Twenty-five seeds were placed on a single steel blue germination blotter (Anchor Paper Co., St. Paul, Minn.) and covered with a 9-mm glass petri dish. Water was added as needed and germination was recorded daily. Germination was defined as visible radicle protrusion through the seedcoat and final germination was calculated after 7 days. A germination test was also carried out in an incubator at a constant $30 \mathrm{C}$ and $35 \% \mathrm{RH}$. The seeds (25) were placed on a single steel blue germination blotter in a 9-mm glass petri dish, moistened with $5 \mathrm{ml}$ of distilled water, and kept in darkness. Final germination was calculated after 7 days.

Primed seeds were also placed in a growth chamber at alternating day/night temperatures ( 38 to $28 \mathrm{C}$ or 32 to $22 \mathrm{C}, 50 \% \mathrm{RH}, 10$ to $14 \mathrm{~h}$, respectively). Fifty seeds for each replication were sown in Speedling polystyrene trays (150 inverted pyramid cell) filled with Metro Mix 300 (Grace Sierra, Calif.). The trays were irrigated as needed with tap water and seedling emergence was recorded daily. The same experiment was conducted in a greenhouse at 34 to $25 \mathrm{C}$ alternating day/ night average temperatures $(14 / 10 \mathrm{~h})$, respectively. The final germination and coefficient of velocity (COV) (Scott et al., 1984) in growth chamber and greenhouse experiments were calculated 10 days after sowing.

All the treatments were arranged in a complete randomized-block design with four replications. The thermogradient table experiment was conducted four times. Per- centage data were arcsin transformed before analysis.

A significant negative relationship between germination percentage and temperature was found on the thermogradient table (Fig. 1). For all treatments, leek seed germination decreased as temperature increased. The slopes of germination for nonprimed seeds and for the $\mathrm{KNO}_{3}$ treatment declined as more temperature increased than those for seeds primed with mannitol, $\mathrm{PEG}_{\mathrm{a}}$, or $\mathrm{PEG}_{\mathrm{n}}$, as osmotica. Germination of nonprimed seed was reduced $>50 \%$ when the temperature increased from 21 to $26 \mathrm{C}$ (Table 1). Germination at $21 \mathrm{C}$ did not differ significantly for the priming treatments and control. As temperature increased, seed primed with mannitol, $\mathrm{PEG}_{\mathrm{a}}$, and $\mathrm{PEG}_{\mathrm{na}}$ had significantly higher germination percentages than the nonprimed or $\mathrm{KNO}_{3}$-primed seeds (Table 1). At 35C, total germination of seeds primed in mannitol was significantly higher than that of seed primed in $\mathrm{PEG}_{\text {na }}, \mathrm{KNO}_{3}$, or the control.

At constant $30 \mathrm{C}$ in an incubator, total and rate $(\mathrm{COV})$ of seedling emergence were significantly higher for seeds primed in mannitol, $\mathrm{PEG}_{\mathrm{a}}$, or $\mathrm{PEG}_{\mathrm{na}}$ than for those of the control or $\mathrm{KNO}_{3}$ treatment (Table 2). At alternating high day/night temperatures (38 to 28C) similar responses were observed. At lower alternating temperatures (32 to $22 \mathrm{C}$ ), significant differences were found in total seedling emergence and rate of emergence only between the priming treatments and control. Total emergence in the greenhouse was higher for all treatments than in the growth chamber. In the greenhouse, total emergence did not differ significantly among treated and nontreated seeds. However, seeds primed via mannitol, $\mathrm{PEG}_{\mathrm{a}}$, or $\mathrm{PEG}_{\text {па }}$ germinated significantly faster (higher COV) than seeds exposed to $\mathrm{KNO}_{3}$ or nontreated seeds (Table 2).

Our results showed that germination of 'Verina' leek seed is severely affected by heat stress. Ellis and Butcher (1987) reported that priming did not influence the ceiling temperature of germination in onion (Allium cepa $\mathrm{L}$.). We conclude that priming reduces the negative effects of high temperature on leek seed germination. Similar results have been reported in lettuce (Cantliffe, 1981; Guedes and Cantliffe, 1980), tomatoes (Ode11 and Cantliffe, 1987), and pansy (Carpenter and Boucher, 1991). Priming leek seed in aerated solutions of D-mannitol, $\mathrm{PEG}_{\text {, }}$, or $\mathrm{PEG}_{\text {па }}$ at $-1.5 \mathrm{MPa}$ for 10 days at $15 \mathrm{C}$ appeared to be effective for increasing total germination, seedling emergence, and velocity of emergence at high temperature. The poor performance of the $\mathrm{KNO}_{3}$ treatment could be associated with damage to the germinating seed by the extended time (10 days) of contact between the salt and the embryo (Cantliffe, 1989). As previously reported in lettuce (Cantliffe, 1981) and dusty miller (Senecio cineraria DC.) (Carpenter, 1990), there were no statistical differences in performance of seeds primed in aerated and nonaerated solutions of PEG-8000. However, the seeds primed in aerated solutions showed less reduction in total germination at unfavorable temperatures. Also, larger quantities of seeds can be primed in aerated solution than with moist surface methods (Akers and Holley, 1986). The D-mannitol was an appropriate substitute for PEG-8000 as an osmoticum. The seeds primed in mannitol had the most rapid and uniform emergence in the thermogradient table, growth chamber, and greenhouse experiments. Priming via D-mannitol or PEG-8000 offers the possibility of improved leek containerized seedling production in Florida and other warm climates by increasing final germination and seedling uniformity. Additional experiments might be necessary to determine the treatment response with other seed lots or leek cultivars and the effect storage time has on the treatments.

\section{Literature Cited}

Akers, W.S. and K.E. Holley. 1986. SPS: A system for priming seeds using aerated polyethylene glycol or salt solutions. HortScience 21:529531 .

Bradford, K.J. 1986. Manipulation of seed water relations via osmotic priming to improve germination under stress conditions. HortScience 21:1105-1110.

Bray, C.M., P.A. Davinson, M. Ashraf, and R.M. Taylor. 1989. Biochemical changes during osmopriming of leek seeds. Ann. Bot. 63:185193.

Brocklehurst, P.A., J. Dearman, and R.L. Drew. 1984. Effects of osmotic priming on seed germination and seedling growth in leek. Scientia Hort. 24:201-210.

Cantliffe, D.J. 1981. Priming of lettuce seed for 
early and uniform emergence under conditions of environmental stress. Acta Hort. 122:29-38 Cantliffe, D.J. 1989. Stand stablishment. Acta Hort. 247:175-179.

Carpenter, W.J. 1990. Priming dusty miller seed: Role of aeration, temperature, and relative humidity. HortScience 25:299-302.

Carpenter, W.J. and J.F. Boucher. 1991. Priming improves high-temperature germination of pansy seeds. HortScience 26:541-544.
Ellis, R.H. and P.D. Butcher. 1987. The effects of priming and 'natural' differences in quality amongst onion seed lots on the response of the rate of germination to temperature and the identification of the characteristics under genotypic control. J. Expt. Bot. 39:935-950.

Guedes, A.C. and D.J. Cantliffe. 1980. Germination of lettuce seeds at high temperature after seed priming. J. Amer. Soc. Hort. Sci. 105:777781
Hardegree, S.P. and W.E. Emmerich. 1990. Effect of polyethylene glycol exclusion on the water potential of solution-saturated filter paper. Plant Physiol. 92:462-466.

Odell, G.B. and D.J. Cantiiffe. 1987. Stand establishment of direct-seeded tomatoes under heat stress. Acta Hort. 198:23-30.

Scott, S.J., R.A. Jones, and W.A. Williams. 1984. Review of data analysis methods for seed germination. Crop Sci. 24:1192-1198. 